\title{
Peran Ayah dalam Pendidikan Anak Perspektif Islam
}

\author{
Dies Tiwi*, Khambali \\ Prodi Pendidikan Guru PAUD, Fakultas Tarbiyah dan Keguruan, \\ Universitas Islam Bandung, Indonesia. \\ *diestiwi30@gmail.com, Khambali@unisba.ac.id
}

\begin{abstract}
Today's society still has the paradigm that nurturing young children is the only role of mothers. Look closerly at the concept and practice of Islamic education turns out that parenting is the job of both parents, the father and the mother, so that the father must also play a part in parenting. In the field especially in the Sindanglaya area of Bandung fathers began engaging in parenting, and there was a change roles in the family. So the author conducted research on the site, to know 1) how the father's understanding of parenting through the role of a father in an Islamic perspective, 2) how the father is involved in parenting, and 3) how the child develops in the upbringing the father provides. The study uses qualitative methods of case studies, using data-collecting techniques, using observation, interviews, field notes and documentation. As for the data analysis procedure used in this study 1) pattern setting, 2) ecition making, 3) chronological time/sequence analysis. Research informants conducted on three families: cases (1) fathers work, mothers don't work, (2) fathers and mothers work, and (3) fathers do not work and mothers do work, the research of the three families, just one family of 1 are ideal for fatherhood in both quality and quantity, fathers and mothers can share roles in parenting. The other two families, the father's role in parenting begins tobe involved, but with quality and quantity differences, it is more or less consistent, and the maternal/grandmother who most instrumental part in parenting.
\end{abstract}

Keywords: Father Role, Parenting, Early Childhood, Islamic Perspective..

Abstrak. Masyarakat saat ini masih memiliki paradigma bahwa pengasuhan terhadap anak usia dini adalah peran ibu saja. Selanjutnya apabila kita cermati lebih jauh tentang konsep dan praktik pendidikan Islam ternyata tugas pengasuhan anak adalah tugas kedua orang tua yaitu ayah dan ibu, sehingga ayah juga harus berperan dalam pengasuhan terhadap anak. Di lapangan khususnya di daerah Sindanglaya Kota Bandung para ayah mulai terlibat dalam pengasuhan terhadap anak, dan terdapat perubahan peran dalam keluarga. Sehingga penulis melakukan penelitian di lokasi tersebut, untuk mengetahui 1) bagaimana pemahaman ayah terkait pengasuhan anak melalui peran seorang ayah dalam perspektif Islam, 2) bagaimana peran ayah dalam pengasuhan terhadap anak usia dini, dan 3) bagaimana perkembangan anak terkait pengasuhan yang diberikan ayah. Penelitian ini menggunakan metode kualitatif studi kasus, dengan teknik pengumpulan data menggunakan observasi, wawancara, catatan lapangan dan dokumentasi. Adapun prosedur analisis data yang digunakan dalam penelitian ini 1) penjodohan pola, 2) pembuatan ekplanasi, 3) analisis deret waktu/kronologis. Informan penelitian dilakukan terhadap tiga keluarga yaitu: kasus (1) ayah bekerja, ibu tidak bekerja, (2) ayah dan ibu bekerja, serta (3) ayah tidak bekerja dan ibu bekerja, Hasil penelitian dari ketiga keluarga, hanya satu keluarga yaitu keluarga 1, yang ideal dalam keterlibatan peran ayah terkait pengasuhan terhadap anak baik secara kualitas maupun kuantitas, serta ayah dan ibu dapat berbagi peran dalam pengasuhan terhadap anak. Dua keluarga lainnya, peran ayah dalam pengasuhan mulai terlibat, tetapi dengan perbedaan kualitas dan kuantitas, masih dilakukan sekadarnya saja atau tidak konsisten, serta peran ibu/nenek yang masih sangat berperan dalam pengasuhan terhadap anak.

Kata Kunci: Peran Ayah, Pengasuhan, Anak Usia Dini, Perspektif Islam 


\section{A. Pendahuluan}

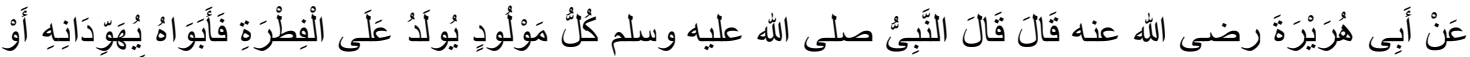

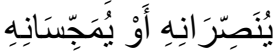

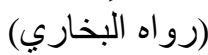

Artinya: Dari Abu Hurairah ra, berkata: Nabi Muhammad SAW bersabda: "Setiap anak yang dilahirkan adalah dalam keadaan suci, maka kedua orang tuanyalah yang membuatnya menjadi Yahudi, Nasrani, atau Majusi”. (Sahih Bukhari, no. hadist: 1401)

Hadits diatas menerangkan bahwa peran ayah yang utama dalam Islam adalah mendidik anak, karena hadits tersebut menegaskan bahwa amanah dan tanggungjawab dalam pendidikan anak ada di pundak kedua orang tua. Pengasuhan anak adalah salahsatu dari bagian pendidikan yang diberikan oleh kedua orang tua, melalui pengasuhan anak akan memperoleh nilai-nilai hidup dari orang tuanya, ibu maupun ayah mereka. Di sisi lain, pengasuhan anak juga merupakan bagian dari perbuatan baik yang ditegaskan Nabi Muhammad SAW, agar dilakukan oleh para suami-ayah kepada keluarga mereka. Dalam berbagai kesempatan Nabi Muhammad SAW, sering mewasiatkan agar para suami-ayah untuk selalu berbuat baik kepada keluarga, istri, dan anak-anaknya. Sesuai dengan hadits:

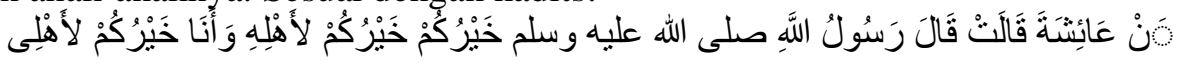

Artinya: Dari Aishah ra, berkata: Rasulullah bersabda: "Sebaik-baik orang diantara kalian adalah yang terbaik perilakunya terhadap keluarganya, dan aku adalah yang terbaik diantara kalian dalam memperlakukan keluargaku" (Sunan Turmudzi, no. hadits: 4269).

Seorang suami-ayah yang baik adalah mereka yang terlibat dalam pengasuhan terhadap anak. Hadits di atas menyimpulkan bahwa menggendong, mengasuh, dan menemani anak bermain adalah bagian dari teladan sunnah Nabi Muhammad SAW, jadi mereka yang melakukan pengasuhan terhadap anak, baik dilakukan oleh ayah maupun ibu adalah mereka yang sedang mengamalkan nilai-nilai luhur Islam dan teladan Nabi Muhammad SAW. Peran ayah dalam pengasuhan anak adalah langkah utama yang harus diperhatikan dari kehidupan keluarga, karena rumah menjadi medan pertama untuk mengamalkan nilai-nilai kemanusiaan, moral, dan perilaku seseorang terhadap keluarganya yang diajarkan Islam (Maisyarah et al. 2017).

Suami atau ayah memiliki peranan atau kedudukan yang sangat berarti dalam mewujudkan keluarga yang sakinah, mawaddah, dan warrahmah. Peran suami di dalam keluarga wajib dilaksanakan sesuai ajaran Islam karena hal tersebut adalah tanggungjawab selaku pemimpin dalam rumah tangga (Arifin. A et al, 2019) sesuai dengan Hanifah (2019), menjelaskan kedudukan ayah dalam Al-Quran yaitu, ayah berperan sebagai: (1) sebagai pemimpin, dalam menjalankan peran sebagai pemimpin ayah harus mampu membimbing dan membuat kebijakan terhadap peraturan di lingkungan keluarga yang telah disepakati. Disamping itu peran ayah sebagai pemimpin terlihat dari tanggungjawab ayah sebagai penyedia keuangan, makanan, pakaian, rumah, dan isinya dari sumber yang halal dan tayyib, (2) sebagai pendidik atau pengasuh.

Candra (2018) menuturkan figur seorang ayah memegang peranan berarti tidak hanya sekedar mencari nafkah untuk keluarga, namun pula berkaitan dengan gaya pengasuhan serta perkembangan anak. Disamping itu, ayah pula memainkan peranan selaku provider (penyedia serta pemberi fasilitas), protector (pemberi proteksi), decision maker (pembentuk keputusan), child specialiser and educator (pendidik serta yang menjadikan anak sosial), serta nurtured mother (pendamping ibu).

Pentingnya keterlibatan peran dalam pengasuhan anak, Allah SWT mengabadikannya dalam QS Luqman. Disana digambarkan seorang ayah yang sangat soleh di dalam Al-Quran yang menjadi pijakan atau ukuran bagaimana seorang ayah seharusnya mendidik anak (bagian dari pengasuhan terhadap anak). Pendidikan dan nasihat-nasihat Lukman untuk anaknya terukir indah di dalam ayat suci Al-Quran, QS Luqman ayat 13-19 yaitu 1) Nasihat untuk tidak mempersekutukan Allah SWT. 2) Nasihat untuk berbakti kepada kedua orangtua. 3) Nasihat untuk berbuat baik kepada sesama meskipun seberat biji sawi. 4) Perintah mendirikan sholat. 5) Nasihat untuk tidak berbuat sombong. 6) Nasihat untuk hidup sederhana. 
Pengasuhan menurut Islam, yaitu merawat dari anak usia dini, memberikan segala sesuatu tentang kebaikan, memberikan pendidikan dan menjaga dari sesuatu yang menyakiti, baik jasmani maupun rohani hingga anak mampu berdiri sendiri menghadapi hidup dan bertanggungjawab atas dirinya sendiri (Yasin, 2020). Dalam Kamus Besar Bahasa Indonesia (KBBI V) pengasuhan berasal dari kata "asuh" yang diartikan sebagai menjaga, melatih, mendidik, merawat, membimbing anak. Sedangkan menurut Berns dalam Afandi (2010) menyatakan jika pengasuhan adalah suatu proses interaksi yang berlangsung dan terjadi terus menerus serta dapat mempengaruhi bukan hanya untuk anak tetapi untuk orang dewasa juga.

Masnipal (2018), dalam bukunya mengemukakan bahwa anak usia dini adalah mereka yang memasuki awal kehidupan, tidak mengertikan apa-apa, dan sepenuhnya memerlukan bantuan orang lain atau orang dewasa. Di Indonesia anak usia dini yaitu anak dengan rentan usia 0 sampai 6 tahun. Seirama dengan Husnuzziadatul K (2018) yang menyatakan anak usia dini adalah anak yang berusia $0-6$ tahun. Anak usia dini merupakan individu yang mengalami perubahan sangat pesat dimana mereka memiliki pola perkembangan dan pertumbuhan dalam berbagai aspek kognitif, fisik, sosial - emosional, seni, bahasa dan moral agama.

Berdasarkan latar belakang yang telah diuraikan, maka pertanyaan penelitian dalam penelitian ini sebagai berikut: (1) bagaimana pemahaman ayah terkait pengasuhan anak melalui peran seorang ayah dalam perspektif Islam? (2) bagaimana peran ayah dalam pengasuhan terhadap anak usia dini? dan (3) bagaimana perkembangan anak terkait pengasuhan yang diberikan ayah? Selanjutnya, tujuan dalam penelitian ini diuraikan dalam pokok-pokok sbb.

1. Dapat mengetahui pemahaman ayah terkait pengasuhan anak melalui peran seorang ayah dalam perspektif Islam.

2. Dapat mengidentifikasi peran ayah dalam pengasuhan terhadap anak usia dini.

3. Dapat mengetahui perkembangan anak terkait pengasuhan yang diberikan ayah.

\section{B. Metodologi Penelitian}

Peneliti menggunakan pendekatan kualitatif dengan metode studi kasus sesuai dengan buku Prof. Dr. Robert K. Yin. Yin (2019) menyebutkan bahwa tujuan penggunaan penelitian studi kasus ialah tidak sekedar menjelaskan bagaimana keadaan objek yang diteliti, tetapi untuk menjelaskan bagaimana keberadaan dan mengapa kasus tersebut dapat terjadi. Sehingga penelitian dilakukan di daerah Sindanglaya Kota Bandung dan informan dalam penelitian ini adalah keluarga yang memiliki anak usia dini dengan kasus 1) Keluarga A (ayah bekerja, ibu tidak bekerja). 2) Keluarga B (ayah dan ibu bekerja). 3) Keluarga C (ayah tidak bekerja dan ibu bekerja). Beserta nenek atau bibi dan guru sekaligus menjadi triangulan.

Dengan teknik pengumpulan data yaitu in-depth interview atau wawancara mendalam, observasi langsung atau observasi partisipan, dokumentasi dan catatan lapangan. Adapun teknik analisis data yang digunakan dalam penelitian ini merujuk kepada buku Prof. Dr. Robert K. Yin, yaitu (1) penjodohan pola, dimana pola yang pertama adalah proposisi awal yang penulis dapat dari studi litelatur (buku atau jurnal) yang berkaitan dengan penelitian. Studi literatur dilakukan saat penulisan proposal hingga penelitian berlangsung. Pola kedua yaitu pola empiris yang penulis dapat dari studi lapangan yaitu observasi dan wawancara terhadap informan. (2) pembuatan eksplanasi, a) membuat proposisi awal, b) melakukan data empiris, c) mencocokan penjodohan pola atau membandingkan temuan-temuan proposisi awal dengan data empiris. (3) analisis deret waktu/ kronologis.

\section{Hasil Penelitian dan Pembahasan}

\section{Pemahaman Ayah Terkait Pengasuhan Anak Melalui Peran Seorang Ayah dalam Perspektif Islam}

Hasil penelitian para ayah memiliki pandangan bahwa pengasuhan anak melalui peran seorang ayah di dalam keluarga adalah sangat penting, karena ayah adalah sosok penting untuk perkembangan anak, anak akan mencontoh segala perilaku orang tua, terutama ayah. Pengasuhan yang diberikan ayah akan membentuk karakter atau jatidiri anak, dan menentukan mental anak. Pernyataan ayah tersebut sesuai dengan Asy dan Ariyanto (2019) yang menyatakan ayah mempunyai peran yang sangat berarti dalam perkembangan anak, baik perkembangan fisik 
ataupun perkembangan mental atau psikologis anak.

Tetapi ayah masih kurang memahami peran ayah dalam perspektif Islam, baik dalam pengetahuan maupun tindakan atau peran itu sendiri. Karena hanya ayah keluarga A yang benarbenar memahami bahwa pengasuhan anak adalah tanggungjawab dan amanah untuk kedua orangtua. Sehingga ayah dan ibu sama-sama saling terlibat dan berperan dalam pengasuhan terhadap anak, serta orangtua menerapkan pengasuhan sesuai ajaran Rasulullah. Ayah keluarga $\mathrm{B}$ dan $\mathrm{C}$ kurang memahami dan kurang keterlibatan dalam pengasuhan karena ayah hanya memberikan pengasuhan sesuai waktu yang ayah miliki atau akan menyerahkan pengasuhan terhadap ibu jika ibu berada di rumah meskipun ayah juga berada di rumah, atau memberikan pengasuhan anak kepada nenek atau bibi jika ibu bekerja. Artinya kedua orangtua tidak saling berperan atau bekerjasama dalam mengasuhan terhadap anak. Hal tersebut sesuai dengan Bastian dan Wahyuni (2017) hasil penelitiannya menyatakan bahwa pengasuhan anak sebagian besar dilakukan oleh istri atau diberikan kepada nenek atau bibi atau orang yang diupah untuk menjaga anak jika ibu bekerja. Tetapi tidak sesuai dengan hadits (Sahih Bukhari, no 1401), karena ayah kurang memahami dan jarang terlibat dalam pengasuhan anak dalam perspektif Islam.

\section{Peran Ayah dalam Pengasuhan Terhadap Anak Usia Dini}

Hasil penelitian, para ayah mulai ikut berperan dalam pengasuhan terhadap anak usia dini, seperti menggendong anak, memandikan anak, menyuapi atau memberi anak makan, mengenalkan anak dengan berbagai hal, serta mengajak anak bermain, hal tersebut sesuai dengan Maisyarah et al (2017). Tetapi hanya dua ayah yang melakukan peran sebagai pencari nafkah untuk memenuhi segala kebutuhan anak, satu ayah lainnya yaitu ayah keluarga $C$ yang tidak menjalankan peran tersebut karena ayah tidak bekerja, sehingga ibu yang harus bekerja untuk mencari nafkah. Hal tersebut tidak sesuai dengan Hanifah (2019), Asy dan Ariyanto (2019), yang menjelaskan peran ayah sebagai pemimpin atau kepala rumah tangga yang bertugas mencari nafkah, serta peran ayah sebagai pemimpin dapat dilihat dari tanggungjawab ayah sebagai pencari nafkah atau sebagai penyedia keuangan, makanan, dll.

Semua ayah berperan sebagai pendidik, pelindung dan pengambil keputusan dalam keluarga dengan perbedaan kualitas dan kuantitas yang ayah berikan, dimana ayah keluarga $\mathrm{A}$ konsisten atau setiap hari melakukan peran pengasuhan tersebut, selain itu ayah sangat berperan dalam mengajarkan atau mendidik anak mengenai pendidikan agama, seperti mengajak anak untuk sholat ke Masjid, mengajarkan anak membaca Iqro, hafalan doa ataupun surat-surat dll, keluarga B sangat jarang terlibat dalam pengasuhan anak karena ayah sering bekerja keluar kota serta ayah kurang memahami kebutuhan dan perkembangan anak, keluarga $\mathrm{C}$ ayah cukup terlibat karena ayah cukup banyak waktu di rumah karena tidak bekerja, tetapi pengasuhan tidak konsisten dan dilakukan diwaktu luang ayah. Pengasuhan diserahkan kepada nenek sang anak. Sesuai dengan Hanifah (2019), Asy dan Ariyanto (2019) yang menyatakan peran ayah sebagai pendidik, pelindung keluarga, pengasuh, dan pemberi keputusan dalam keluarga.

Serta peran ayah dalam pengasuhan yaitu mengenalkan anak mengenai aturan dan disiplin. Sehingga pengasuhan anak lebih mudah dilakukan ayah dibandingkan dengan ibu, karena ayah lebih tegas dalam memberikan pengasuhan dan anak lebih segan terhadap ayah. Hal tersebut sejalan dengan U. Nila Auni (2017), dan Maisyarah, et.al (2017) yang menyatakan peran ayah dalam pengasuhan indentik dengan karakter yang keras serta tegas. Sehingga pengasuhan ayah akan mengajarkan anak bagaimana rasa tanggungjawab, disiplin dan hidup mandiri. Pengasuhan dalam pandangan Islam yaitu merawat anak dari usia dini, memberi segala sesuatu yang menyakiti, baik jasmani mapun rohani sampai anak mandiri dan mampu bertanggungjawab terhadap dirinya (Yasin, 2020). Pernyataan tersebut sesuai dengan fakta dilapangan dimana ayah mulai terlibat dalam pengasuhan, merawat anak, dan juga pendidikan anak meskipun terdapat perbedaan kualitas dan kuantitas yang ayah berikan, ayah yang paling terlibat adalah keluarga A, dan ayah yang jarang sekali terlibat yaitu ayah keluarga B.

\section{Perkembangan Anak Terkait Pengasuhan yang Diberikan Ayah}

Hasil penelitian ayah yang lebih banyak waktu untuk anak dalam pengasuhan, kognitif anak lebih bagus, anak dapat berpikir kritis, rasa ingin tahu anak sangat tinggi, bahasa anak bagus, anak memiliki kosakata lebih banyak, anak dapat menyampaikan perasaan, anak lebih percaya 
diri, dan anak lebih cepat tanggap dalam menerima pembelajaran. Hal tersebut berlangsung terhadap anak keluarga A dan anak keluarga $\mathrm{C}$, sedangkan ayah yang tidak banyak waktu dalam pengasuhan terhadap anak seperti ayah keluarga B, kognitif anak kurang baik/ lemah. Seseuai dengan riset Vita dalam Aryanti (2017), keterlibatan ayah dalam keluarga anak memiliki rasa humor, lebih percaya diri dan mempunyai motivasi belajar. Serta dari buku penyuluhan bina keluarga balita bagi kader dalam Purnamasari (2015), keterlibatan ayah dalam pengasuhan kepada anak usia dini memiliki peran yang sangat penting dalam perkembangan anak, yaitu kognitif anak lebih cerdas, bahasa anak bagus, anak memiliki prestasi di sekolah, anak lebih aktif, serta anak memiliki sosial emosional yang positif, yaitu: anak selalu merasa aman, mudah beradaptasi atau bergaul dengan lingkungan, memiliki empati, tidak mudah stress dan terhindar dari konflik.

Fakta di lapangan ayah yang terlibat dalam pengasuhan dan terlibat dalam aktivitas menstimulasi social-emosional anak, seperti ayah keluarga $\mathrm{B}$ dan ayah keluarga $\mathrm{C}$ mengenalkan anak dengan dunia luar, mengajarkan anak bersosialisasi secara langsung, anak lebih mudah bergaul, memiliki empati, dan terhindar dari konflik atau bermasalah dengan teman. Selanjutnya penelitian yang dilakukan Septiani dan Nasution (2018) dalam penelitiannya mengungkapkan hasil penelitian menunjukkan bahwa ada hubungan antara perkembangan kecerdasan moral anak dengan peran keterlibatan ayah dalam pengasuhan.

Tetapi dilapangan berbeda dengan ayah lainnya, ayah keluarga A yang membatasi anak bermain diluar rumah, hanya memberikan teladan, nasehat melalui film atau buku dalam social anak. Anak keluarga A memang mudah bergaul dan cepat beradaptasi dengan lingkungan baru, karena peran ayah dalam pengasuhan konsisten dilakukan. Tetapi untuk bermain secara kelompok atau dengan aturan, anak selalu ingin menjadi yang pertama, dan ingin selalu menang karena ayah tidak menstimulasi social anak secara langsung dengan membatasi anak bermain dilingkungan rumah. Pernyataan Purnamasari dan penelitian yang dilakukan oleh Septiani dan Nasution, tidak sesuai dengan fakta dilapangan. Karena keterlibatan ayah dalam pengasuhan juga penting dilihat bagaimana ayah mengasuh sangat mempengaruhi social emosional anak. Kemudian ditemukan dalam penelitian ini, kegiatan yang selalu ayah berikan terhadap anak akan menjadi minat dan bakat anak. Seperti anak keluarga $\mathrm{C}$ meskipun lemah dalam kognitif dan bahasa tetapi ananda menonjol dalam bidang seni, karena ayah yang selalu menemani anak menggambar dan mewarnai.

\section{Kesimpulan}

Berdasarkan pembahasan dalam penelitian ini, peneliti menyimpulkan beberapa hasil penelitian sebagai berikut:

1. Pemahaman ayah terkait pengasuhan anak melalui peran seorang ayah dalam perspektif Islam. Ayah keluarga 1 sangat baik karena benar-benar memahami serta menjalan pengasuhan sesuai ajaran Islam atau sunnah Nabi Muhammad SAW. Kemudian ayah keluarga 2 kurang, dalam pemahaman maupun keterlibatan ayah terkait pengasuhan kerena ayah sangat jarang terlibat dalam pengasuhan. Serta ayah keluarga 3 cukup baik dalam pemahaman, tetapi kurang dalam keterlibatan terkait pengasuhan.

2. Peran ayah dalam pengasuhan terhadap anak usia dini adalah pendidik, merawat, pelindung keluarga, pencari nafkah, dan pengambil keputusan. Hanya ayah keluarga 1 yang ideal melakukan peran dan keterlibatan ayah dalam pengasuhan. Karena ayah lainnya kurang maksimal dalam perannya terkait pengasuhan, ayah hanya memberikan pengasuhan hanya diwaktu luang ayah atau seadanya.

3. Perkembangan anak terkait pengasuhan yang diberikan ayah, ternyata bukan hanya keterlibatan dalam pengasuhan saja yang dibutuhkan untuk hasil perkembangan anak, tetapi pemahaman ayah terkait pengasuhan, serta cara ayah dalam memberikan pengasuhan juga mempengaruhi perkembangan anak dan mempengaruhi minat dan bakat anak. Dalam kasus ini 1) anak keluarga A menonjol dalam perkembangan moral agama, kognitif, hafalan, bahasa dan juga fisik motoric, tetapi anak lemah dalam bersosialisasi, anak tidak sportif dan selalu ingin menjadi yang pertama. 2) anak keluarga B menonjol dalam perkembangan seni, tetapi kurang dalam aspek kognitif sedangkan 
perkembangan lainnya sesuai dengan usianya. Sedangkan 3) anak keluarga C perkembangan anak sesuai dengan standar tingkat pencapaian perkembangan anak.

\section{Acknowledge}

Allah SWT yang memberikan kemudahan serta ilmu untuk penulis, kedua orangtua, para pembimbing, seluruh informan penelitian, keluarga besar, teman sepejuangan skripsi, serta pihak-pihak lain yang tidak bisa semua penulis sebutkan satupersatu. Terima kasih atas doa, bantuan serta motivasi yang diberikan untuk peneliti.

\section{Daftar Pustaka}

[1] Baqi Mfa. Shahih Bukhari Muslim. 2017;

[2] Nashiruddin A-Am. Shahih Sunan Tirmidzi. 2014;1-14.

[3] Maisyarah, Ahmad A, Bahrun. Peran Ayah Pada Pengasuhan Anak Usia Dini Dalam Keluarga Di Kecamatan Darussalam, Kabupaten Aceh Besar. J Chem Inf Model [Internet]. 2017;53(9):1689-99. Available From: Http://Www.Jim.Unsyiah.Ac.Id/Paud/Article/Viewfile/5786/4498

[4] Arifin A. Implikasi Pendidikan Dari Qs At-Taghaabun Ayat 14 Tentang Perilaku Suami Dalam Berinteraksi Dengan Istri Dan Anak Terhadap Peran Suami Dalam Keluarga Educational Implications Of Qs At-Taghaabun Verse 14 About Husband' S Behavior In Interacting With Wife. 2019;(2):291-6.

[5] Hanifah Dsa. Peran Ayah Dalam Pembentukan Karakter Anak Perspektif Alquran. 2019;170.

[6] Candra S. Pelaksanaan Parenting Bagi Orang Tua Sibuk Dan Pengaruhnya Bagi Perkembangan Anak Usia Dini. Thufula J Inov Pendidik Guru Raudhatul Athfal. 2018;5(2):267.

[7] Qur'an. Kementerian Agama Ri;

[8] Yasin. Tanggung Jawab Orang Tua Kepada Anak Di Era Digital Perspektif Hukum Keluarga Islam Di Indonesia. Profesi [Internet]. 2020;17(2). Available From: Journals.Itspku.Ac.Id

[9] V K. Kamus Besar Bahasa Indonesia V [Internet]. V. Badan Pengembangan Bahasa Dan Perbukuan, Kementerian Pendidikan Dan Kebudayaan Republik Indonesia; Available From: Kbbi.Kemdikbud.Go.Id

[10] Afandi Mi. Hp Pengembangan Buku Panduan Pengasuhan Mengembangkan Potensi Membaca Anak Prasekolah. Fak Bahas Dan Seni Univ Negeri Semarang. 2010;

[11] Masnipal. Menjadi Guru Paud Profesional. 2018. 384 P.

[12] Husnuzziadatul Khairi. Karakteristik Perkembangan Anak Usia Dini Dari 0-6 Tahun. J Warn [Internet]. 2018;2(2):15-28. Available From: Ejournal.Iaiig.Ac.Id? Index.Php? Warna? Article? Download

[13] Yin Rk. Studi Kasus Desain \& Metode. Cetakan 16. Depok: Rajawali Pers; 2019.

[14] Asy H, Ariyanto A. Gambaran Keterlibatan Ayah Dalam Pengasuhan Anak (Paternal Involvement) Di Jabodetabek. Intuisi J Psikol Ilm. 2019;11(1):37-44.

[15] Bastian A, Wahyuni S. Sosialisasi Peran Ayah Dalam Pengasuhan Anak Usia Dini Di Tk Baiturrahman Pekanbaru. J Prodikmas Has ... [Internet]. 2017;1(2):1-7. Available From: Http://Jurnal.Umsu.Ac.Id/Index.Php/Prodikmas/Article/View/1254

[16] Maisyarah. Peran Ayah Pada Pengasuhan Anak Usia Dini Dalam Keluarga Di Kecamatan Darussalam Kabupaten Aceh Besar [Internet]. Universitas Syiah Kuala; 2016. Available From: Https://Etd.Unsyiah.Ac.Id/Baca/Index.Php?Id=33852\&Page=4

[17] U. Nila Auni. Hubungan Peran Ayah Dengan Penyesuaian Diri Pada Anak Usia 4-6 Tahun Di Desa Gelang, Kecamatan Rakit, Kabupaten Banjarnegara. 2017;122.

[18] Aryanti Y. Peran Ayah Dalam Pengasuhan Anak Usia Dini. J Pendidik Dompet Dhuafa. 2017;7(1):21-4.

[19] Purnamasari Se. The Role Of Fathers In Children' S Upbringing Masing-Masing . Ayah 
108 Dies Tiwi, et al.

Dan Ibu Memiliki Peran Dan Pengajaran Kepada Anak . Berbagai Budaya Ibu . Oleh Karena Itu , Baik Buruknya Perilaku Proses Dewasanya Kelak . Sosok Ayah Mampu Memberi Yang Anak Lingkunganny. J Insight. 2015;17(2):81-90.

[20] Septiani D, Nasution In. Peran Keterlibatan Ayah Dalam Pengasuhan Bagi Perkembangan Kecerdasan Moral Anak. J Psikol. 2018;13(2):120. 